\title{
A rare view: giant liver abscess with underlying liver metastases
}

\author{
Leonor Vasconcelos Matos, ${ }_{1}^{1}$ Patricia Moniz, ${ }^{2}$ Jorge Oliveira Dantas, ${ }^{3}$ Arturo Botella ${ }^{3}$
}

'Department of Oncology, Hospital Sao Francisco Xavier, Lisboa, Portugal

${ }^{2}$ Medicina III, Hospital São Francisco Xavier-Centro Hospitalar Lisboa Ocidental/ NOVA Medical School,

Faculdade de Ciências Médicas, Universidade Nova de Lisboa, Lisbon, Portugal

${ }^{3}$ Department of Internal Medicine, Hospital Sao Francisco Xavier, Lisboa, Portugal

\section{Correspondence to}

Dr Leonor Vasconcelos Matos, analeonormatos9@gmail.com

Accepted 14 April 2017
CrossMark

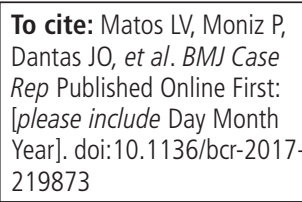

To cite: Matos LV, Moniz $\mathrm{P}$ Dantas JO, et al. BMJ Case Rep Published Online First: [please include Day Month Year]. doi:10.1136/bcr-2017 219873

\section{DESCRIPTION}

Liver abscess (LA) refers to a suppurated cavity caused by the invasion of liver parenchyma, most commonly by Gram-negative bacteria. Although rare, it is potentially life-threatening. Giant LA $(>10 \mathrm{~cm})$ is even more uncommon. ${ }^{1}$ Symptoms and signs are non-specific and the diagnosis relies essentially on imaging with ultrasound (US) and CT scan. Treatment is based on antimicrobials, abscess drainage and approach to the underlying disease. $^{2}$ For pyogenic LA, prompt initiation of empirical broad-spectrum intravenous antibiotics, ${ }^{2}$ usually a third-generation cephalosporin plus metronidazole, is essential with subsequent adjustment to culture and sensitivity, usually for 10-14 days, depending on clinical and radiological response. Together with CT scan or US-guided percutaneous catheter drainage (PD), it is the initial treatment of choice. ${ }^{1}$ However, large LA $>5 \mathrm{~cm}$ predicts failure of PD and the need for surgical drainage. ${ }^{3}$ Malignancy and multiloculation are also risk factors for therapy failure. The

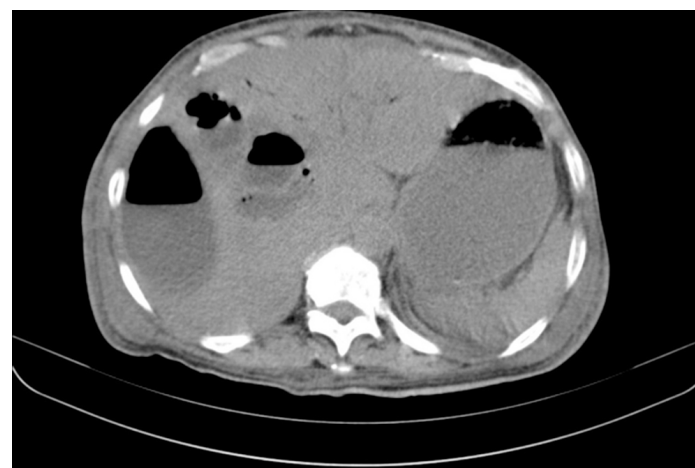

Figure 1 Thoracoabdominal CT scan, axial.

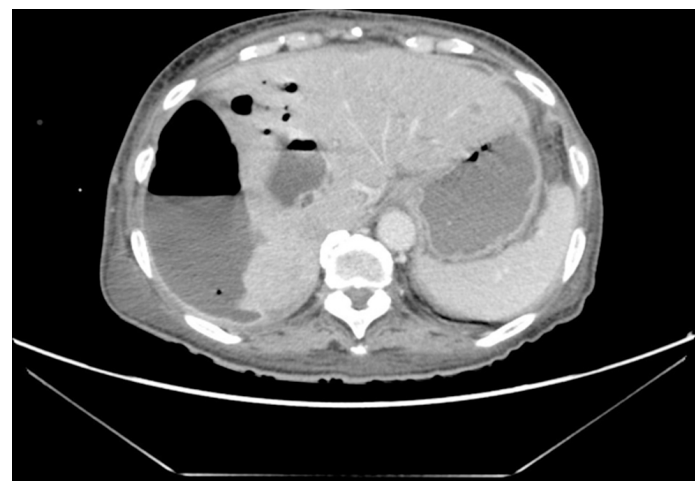

Figure 2 Thoracoabdominal CT scan, axial, with intravenous contrast, after drainage, abscess size progression, one giant. best outcome is achieved with close coordination of a multidisciplinary team and rigorous drain management protocol. ${ }^{1}$ We report the case of a 74-year-old woman with pancreatic carcinoma with liver metastasis that required a biliary prosthesis. She presented with fever, abdominal pain and jaundice and was diagnosed with cholangitis, starting intravenous antibiotics, adjusted to blood cultures (Streptococcus anginosus, Raoultella

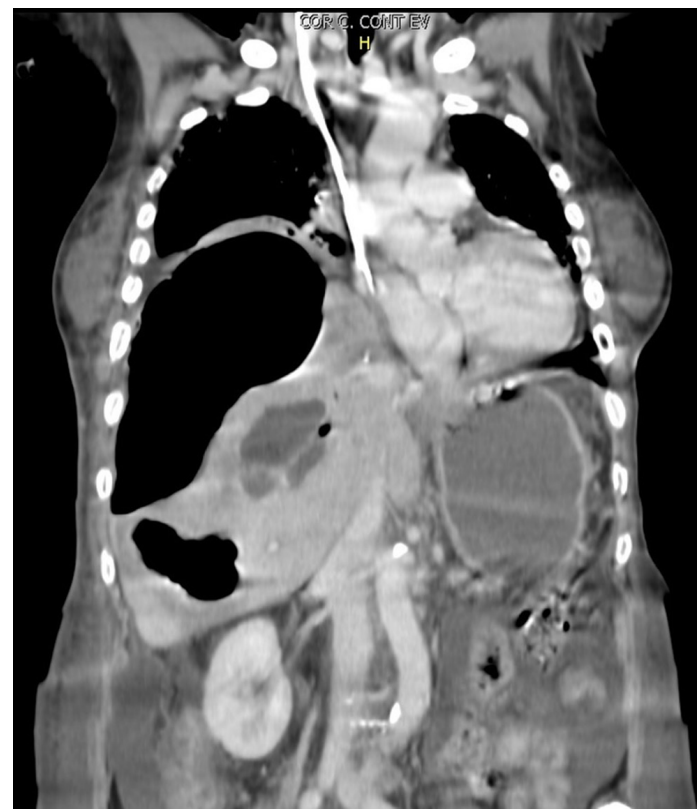

Figure 3 Thoracoabdominal CT scan, coronal, with intravenous contrast, after drainage, abscess size progression, one giant.

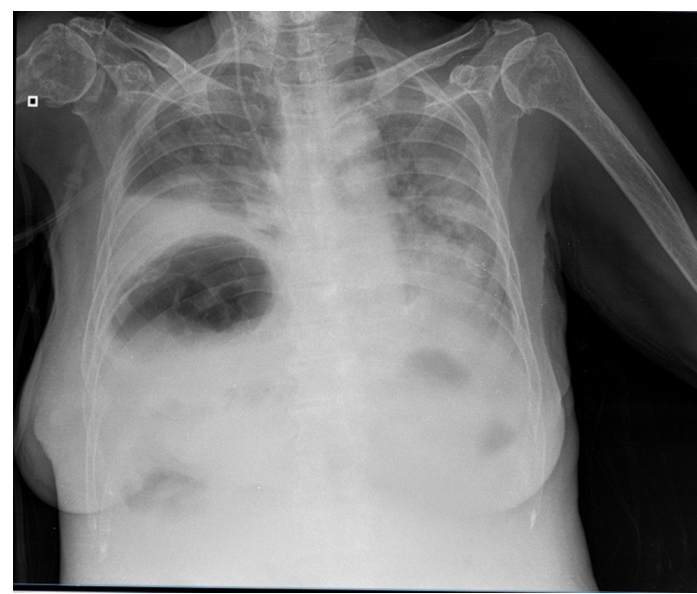

Figure 4 Thoracic X-ray, posteroanterior, showing air under the right side of the diaphragm. 
planticola and Enterobacter cloacae). An endoscopic retrograde cholangiopancreatography showed occlusion of the prosthesis, then replaced. After 5 days of unresolved infection, a new CT scan revealed multiple liver metastases and abscesses (figure 1). A CT-guided percutaneous drainage was performed: E. cloacae, Enterococcus faecalis and Candida glabrata were isolated in the pus, and antimicrobials adjusted. After 4 days, the patient got worse, with signs of severe organ failure. CT scan revealed a giant subcapsular liver abscess, with

\section{Learning points}

- Giant liver abscess is a very rare disease, but with up to $46 \%$ mortality.

- Prompt initiation of parenteral broad-spectrum antibiotics, early ultrasound or CT to confirm diagnosis, percutaneous drainage, tissue culture and repeated scans, if sepsis persists, are the main approaches to achieve the best optimal outcome.

- Giant size and multiloculation are predictors of failure of percutaneous drainage and need for surgical drainage.
$16 \mathrm{~cm}$, and worsening of the previous abscesses (figures 2-4). The patient died 2 days later.

Acknowledgements We thank Dr Renato Guerreiro, MD, Dr Manuel Arajo, MD, and Dr Luis Costa, MD, for their contribution to data collection and to Dr Candida Fonseca, MD, PhD, for herrevision and comments.

Contributors LVM had the most substantial contribution to the conception and design of the manuscript. LVM, AB, PM and JOD followed the patient in question during hospitalisation. LVM prepared the manuscript draft with important scientific contribution from author AB. All authors approved the final manuscript.

Competing interests None declared.

Patient consent Obtained from next of kin.

Provenance and peer review Not commissioned; externally peer reviewed.

(C) BMJ Publishing Group Ltd (unless otherwise stated in the text of the article) 2017. All rights reserved. No commercial use is permitted unless otherwise expressly granted.

\section{REFERENCES}

1 Ahmed S, Chia CL, Junnarkar SP, et al. Percutaneous drainage for giant pyogenic liver abscess-is it safe and sufficient? Am J Surg 2016;211:95-101.

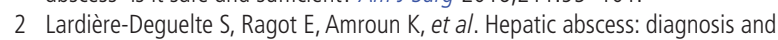
management. J Visc Surg 2015;152:231-43.

3 Tan Y-M, Chung AY-F, Chow PK-H, et al. An appraisal of Surgical and Percutaneous Drainage for Pyogenic liver Abscesses Larger than $5 \mathrm{~cm}$. Ann Surg 2005;241:485-90.

Copyright 2017 BMJ Publishing Group. All rights reserved. For permission to reuse any of this content visit http://group.bmj.com/group/rights-licensing/permissions.

BMJ Case Report Fellows may re-use this article for personal use and teaching without any further permission.

Become a Fellow of BMJ Case Reports today and you can:

- Submit as many cases as you like

- Enjoy fast sympathetic peer review and rapid publication of accepted articles

- Access all the published articles

- Re-use any of the published material for personal use and teaching without further permission

For information on Institutional Fellowships contact consortiasales@bmjgroup.com

Visit casereports.bmj.com for more articles like this and to become a Fellow 